\title{
Analisis Standard Hotel Mesra Muslim di Malaysia Berdasarkan Perspektif Maqasid Syariah
}

\author{
An Analysis of Muslim Friendly Hotel Standards in Malaysia According to the \\ Maqasid Syariah Perspective
}

\author{
MOHAMMAD ZAINI YAHAYA*, MUHAMMAD ADIB SAMSUDIN \& \\ MOHD IZHAR ARIFF MOHD KASHIM1
}

\begin{abstract}
Malaysia is far advanced in introducing the Muslim friendly hotel segment as an Islamic tourism product. Malaysian hoteliers refer to three standards when offering Muslim friendly hotel services, which are namely the MS 2610: 2015 Muslim Friendly Hospitality Services Requirements, Crescent Rating Standard and Salam Standard. Moreover, CrescentRating Standard and Salam Standard have become standards for assessing Muslim friendly hotels at the international level. This study evaluated these standards in terms of their adherence to the Maqasid Syariah principle. Criteria for fulfilling these standards were presented and analyzed according to the five kulliyyat found in the Maqasid Syariah, such as protection of religion, life, intelect, lineage and wealth. Findings show that these standards strongly emphasize criteria related to safeguarding religion, such as performing prayers and fasting; safeguarding lives, such as consuming halal food; safeguarding the mind, such as abstaining from consuming alcohol beverages as well as safeguarding familial lineage, such as separating individuals according to their gender in swimming pools and spas. However, safeguarding lives, from the self-security aspect, and safeguarding property were not part of the criteria that determines the standards even though both these criteria are the fundamental needs of hotel guests. The failure to include these criteria has made these standards lose their holistic nature as well as become incapable of becoming evaluating standards that are completely detached from contemporary conventional standards.
\end{abstract}

Keywords: halal certification, halal tourism, maqasid syariah, Muslim friendly hotel, syariah compliant hotels

State of The Global Islamic Economy Report (SGIE) 2019/20 melaporkan Malaysia sedang menerajui Indikasi Ekonomi Islam Global khususnya dalam bidang kewangan Islam, makanan halal dan pelancongan halal. Laporan yang sama menganggarkan pasaran pelancongan Muslim global meningkat sehingga ke US\$274 billion pada tahun 2024 (Dinar Standard 2019). Malaysia muncul sebagai sebagai destinasi pelancongan Muslim teratas dalam kalangan negara-negara Pertubuhan Persidangan Islam (OIC) semenjak tahun 2010 (Crescentrating 2018). Penginapan

\footnotetext{
${ }^{1}$ Mohammad Zaini Yahaya* (corresponding author) Ph.D., senior lecturer at Research Centre for Sharia, Faculty of Islamic Studies, Universiti Kebangsaan Malaysia, 43600 BANGI, Selangor, Malaysia, email: zainiyahya@ukm.edu.my; Muhammad Adib Samsudin, Ph.D., senior lecturer at Research Centre for Sharia, Faculty of Islamic Studies, Universiti Kebangsaan Malaysia, 43600 BANGI, Selangor, Malaysia, email: adib@ukm.edu.my; Mohd Izhar Ariff Mohd Kashim, Ph.D., associate professor at Research Centre for Sharia, Faculty of Islamic Studies, Universiti Kebangsaan Malaysia, 43600 BANGI, Selangor, Malaysia, email: izhar@ukm.edu.my.
} 
merupakan prasarana paling penting bagi pelancong Muslim dan merupakan kunci utama dalam pembangunan indusrti pelancongan halal (Hardius, Nurdin \& Lia Estika Sari 2020) Hotel mesra Muslim merupakan salah satu segmen penting khususnya dalam memenuhi keperluan pelancongan Muslim. Sesuai sebagai sebuah negara Islam yang menjadi tumpuan pelancong Muslim seluruh dunia, pemain industri perhotelan di Malaysia giat menawarkan hotel berkonsepkan mesra Muslim. Terdapat beberapa buah hotel di Malaysia mengisyhtiharkan secara terbuka sebagai hotel patuh syariah atau hotel Islamik. Namun terdapat juga hotel-hotel yang tidak mendakwa demikian, tetapi tetap menawarkan perkhidmatan yang patuh syariah (Nor Azizah Tukirana \& Nor 'Azzah Kamri 2018: 63). Realitinya kebanyakan pengendali hotel masih kabur berkenaan kriteria sebenar hotel Islamik atau hotel patuh Syariah (Mohd Hyrul, Rozila \& Noor Azimin 2017). Terminologi hotel mesra Muslim dan hotel patuh Syariah juga pernah diperdebatkan dari sudut kesesuaiannya pada masa kini. Namun menyedari kesukaran mencapai tahap kepatuhan Syariah dalam industri perhotelan semasa, akhirnya istilah hotel mesra Muslim lebih banyak digunakan (Majdah \& Noriah 2017). Namun begitu, penggunaan terminologi hotel mesra Muslim bukan bermakna pengendali hotel boleh mengorbankan prinsip-prinsip penting dalam Syariah, sebaliknya keperluan seorang pelancong Muslim hendaklah dipenuhi. Untuk mengkategori keperluan seorang Muslim, konsep Maqasid Syariah perlu dijadikan parameter (Fisol et al. 2019). Herarki keperluan seorang Muslim secara vertical disusun mengikut tahap daruriyyat, hajiyyat serta tahsiniyyat dan secara horizontalnya merangkumi penjagaan lima perkara iaitu agama, nyawa, akal, maruah dan harta.

\section{Standard Hotel Mesra Muslim}

Sehingga kini tiada satu standard khusus yang boleh dijadikan tanda aras pelancongan Muslim (Muslim tourism) termasuk hotel mesra Muslim (Organisation of Islamic Cooperation 2018; Junaidi 2020). Di Malaysia, Jabatan Standard Malaysia memperkenalkan MS 2610: 2015 Muslim Friendly Hospitality Services - Requirements sebagai penanda aras bagi hotel mesra Muslim. Tripez Travel iaitu sebuah agensi swasta di Malaysia pula menawarkan Salam Standard sebagai sistem penarafan hotel mesra Muslim. Salam Standard mendapat pengiktirafan oleh kerajaan Malaysia menerusi Kementerian Pelancongan dan Kebudayan Malaysia (MOTAC) dan Islamic Tourism Centre (ITC). Crescentrating Pte Ltd. sebuah agensi swasta yang berpengkalan di Singapura juga menawarkan khidmat penarafan dan akreditasi halal-mesra pelancongan (halalfriendly travel) termasuk hotel mesra Muslim. Malah Crescentrating dengan kerjasama Mastercard telah berjaya menghasilkan indeks yang diberi nama Global Muslim Travel Index (GMTI) yang menjadi rujukan paling berautoriti dalam segmen pelancongan halal mesra Muslim setakat ini (Cuesta-Valiño, Bolifa \& Núñez-Barriopedro 2020). Ketiga-tiga agensi ini menawarkan standard hotel mesra Muslim yang berbeza.

\section{Kriteria MS 2610: 2015: Muslim Friendly Hospitality Services - Requirements}

Standard ini merupakan standard Malaysia pertama dalam sektor ini. Ia adalah hasil inisiatif International Institute for Halal Research \& Training (INHART), Universiti Islam Antarabangsa Malaysia (UIAM) dengan penglibatan Jabatan Standard Malaysia. Wakil-wakil agensi lain dalam pelancongan juga dilibatkan dalam membina standard ini seperti Tourism Centre (ITC), Tourism Malaysia, Malaysia Association of Hotel Owners (MAHO), Malaysia Association of Hotel (MAH), Malaysia Association of Tour and Travel Agents (MATTA), Bumiputera Travel and Tour Agents Association of Malaysia (Bumitra) dan Malaysian Tourist Guides Council (MTGC) (Islamic Toursim Centre 2016).

MS 2610: 2015 tidak hanya terpakai untuk penginapan sahaja, malah ia merangkumi juga pakej pelancongan dan pemandu pelancong. Standard penginapan merangkumi lima komponen utama iaitu: bilik, makanan dan minuman, musolla awam, tandas awam serta prasarana rekreasi 
dan kesihatan. Komponen-komponen ini boleh dilihat dalam jadual berikut (Department of Sandard Malaysia 2015):

Jadual 1: Lima Komponen Berkaitan Penginapan dalam Standard MS: 2610: 2015

\begin{tabular}{|c|c|}
\hline Komponen & Aspek \\
\hline Bilik & $\begin{array}{ll}\text { 1. } & \text { Bersih } \\
\text { 2. } & \text { Kemudahan yang membolehkan pelaksanaan wuduk dan solat } \\
\text { 3. } & \text { Kemudahan bersuci menurut syarak } \\
\text { 4. } & \text { Tidak disediakan makanan beralkohol atau memabukkan } \\
\text { 5. } & \text { Disediakan keperluan Muslim yang lain atas permintaan seperti, } \\
& \text { sejadah, telekung dan al-Quran. }\end{array}$ \\
\hline $\begin{array}{l}\text { Makanan dan } \\
\text { Minuman }\end{array}$ & $\begin{array}{l}\text { 1. Dapur yang mendapat pensijilan halal oleh badan berautoriti. } \\
\text { 2. Menyediakan informasi dan perkhidmatan sepanjang bulan Ramadan } \\
\text { termasuk iftar dan sahur. }\end{array}$ \\
\hline Musolla awam & $\begin{array}{l}\text { 1. Musolla terletak di lokasi yang bersesuaian dan terdapat papan tanda } \\
\text { khusus. } \\
\text { 2. Bersih, mempunyai sistem pengudaraan yang baik dan diselenggara } \\
\text { dengan baik } \\
\text { 3. Memiliki perkara asas seperti tanda arah qiblat, telekung serta ruang } \\
\text { solat dan wuduk yang terpisah antara lelaki dan wanita. }\end{array}$ \\
\hline Tandas awam & $\begin{array}{ll}\text { 1. } & \text { Bersih. } \\
\text { 2. } & \text { Kemudahan yang membolehkan pengguna Muslim bersuci menurut } \\
\text { syarak termasuk produk yang digunakan untuk bersuci. }\end{array}$ \\
\hline $\begin{array}{l}\text { Prasarana rekreasi } \\
\text { dan kesihatan }\end{array}$ & $\begin{array}{l}\text { 1. Bersih dan diselenggarakan dengan baik. } \\
\text { 2. Tandas yang disediakan membolehkan pengguna Muslim bersuci } \\
\text { menurut syarak. } \\
\text { 3. Jika ada keperluan, pihak penginapan hendaklah menyediakan fasiliti } \\
\text { mesra Muslim. }\end{array}$ \\
\hline
\end{tabular}

\section{Kriteria Crescent Rating}

Standard ini pada asalnya dibina oleh Prof. Madya Dr Nor'ain Othman dari Universiti Teknologi Mara (UiTM) dan Prof. Shaya'a Othman dari Universal Crescent Standard Center (UCSC) menerusi hasil kajian mereka. Dengan bantuan dan sokongan kewangan daripada UiTM dan UCSC, Islamic Quality Standard for Hotels (IQS) dihasilkan sebagaimana jadual berikut (Nor'aini \& Shaya'a 2012; Che Musa et al. 2014):

Jadual 2: Keperluan Asas dalam Penarafan IQS

\begin{tabular}{|c|c|}
\hline IQS & Keperluan Asas \\
\hline IQS-1 & $\begin{array}{l}\text { 1. Bilik tidur (1 queen/2 saiz standard dan telefon). Akses yang mudah } \\
\text { serta kakitangan bertugas } 24 \text { jam. } \\
\text { 2. Panduan arah kiblat, sejadah dan jadual solat. } \\
\text { 3. Menyediakan sarapan pagi yang halal. } \\
\text { 4. Menyediakan minimum dua musolla. }\end{array}$ \\
\hline IQS-2 & 1. Restoran yang menyediakan makanan halal. \\
\hline IQS-3 & 1. Menyediakan makanan halal sepanjang masa. \\
\hline IQS-4 & 1. Menjadualkan penggunaan kolam renang dan spa mengikut jantina. \\
\hline IQS-5 & $\begin{array}{l}\text { 1. Bilik yang luas untuk ruang bersolat. } \\
\text { 2. Musolla mengikut jantina. }\end{array}$ \\
\hline IQS-6 & $\begin{array}{l}\text { 1. Spa dan gymnasium berdasarkan jantina. } \\
\text { 2. Prasarana tambahan seperti salun dan arked butik yang dipisahkan } \\
\text { jantina. } \\
\text { 3. Menyediakan juadah buka puasa dan sahur. }\end{array}$ \\
\hline
\end{tabular}




\begin{tabular}{|l|ll|}
\hline & 1. & Dua kolam renang mengikut jantina. \\
2. & Dua spa mengikut jantina. \\
IQS-7 & 3. & Empat musolla yang boleh digunakan oleh penghuni hotel. \\
& 5. & Hiburan bagi keluarga berdasarkan jantina. \\
& 6. & Bilik yang mengandungi bidet. \\
\hline
\end{tabular}

Berdasarkan IQS ini, UCSC membina sistem penarafan hotel mesra Muslim sebagai nilai tambah bagi pengusaha-pengusaha hotel. UCSC menjadikan tujuh peringkat dalam penarafan yang dijenamakan sebagai CrescentRating Standard. Aspek yang menjadi kriteria utama dalam penarafan ialah tahap prasarana makanan halal, tahap prasarana solat, tahap perkhidmatan sepanjang Ramadan (puasa) dan tahap kebebasan daripada aktiviti tidak halal di hotel. Semua kriteria ini dipaparkan di dalam laman web crescentrating.com sebagaimana berikut (Crescentrating 2018):

Jadual 3: Kriteria Crescentrating Standard

\begin{tabular}{|c|c|c|c|}
\hline $\begin{array}{c}\text { Prasarana Makanan } \\
\text { Halal }\end{array}$ & Prasarana Solat & $\begin{array}{c}\text { Perkhidmatan } \\
\text { Sepanjang Ramadan }\end{array}$ & $\begin{array}{c}\text { Bebas daripada } \\
\text { Aktiviti tidak Halal }\end{array}$ \\
\hline $\begin{array}{l}\text { 1. Senarai restoran } \\
\text { halal di kawasan } \\
\text { sekitar? }\end{array}$ & $\begin{array}{l}\text { 1. Senarai masjid di } \\
\text { kawasan sekitar? }\end{array}$ & $\begin{array}{l}\text { 1. Keperluan asasi } \\
\text { untuk buka puasa (air } \\
\text { dan kurma)? }\end{array}$ & $\begin{array}{l}\text { 1. Terdapat kelab } \\
\text { malam atau kasino? }\end{array}$ \\
\hline $\begin{array}{l}\text { 2. Makanan atau } \\
\text { menu halal? }\end{array}$ & $\begin{array}{l}\text { 2. Bersedia menjawab } \\
\text { soalan berkenaan } \\
\text { waktu solat dan arah } \\
\text { kiblat? }\end{array}$ & $\begin{array}{l}\text { 2. Juadah berbuka } \\
\text { puasa sepanjang } \\
\text { Ramadan? }\end{array}$ & $\begin{array}{l}\text { 2. Terdapat rangkaian } \\
\text { televisyen dewasa } \\
\text { atau aktiviti tidak } \\
\text { halal? }\end{array}$ \\
\hline $\begin{array}{l}\text { 3. Makanan halal di } \\
\text { mini-bar? }\end{array}$ & $\begin{array}{l}\text { 3. Mushaf al-Quran, } \\
\text { sejadah atau jadual } \\
\text { waktu solat } \\
\text { disediakan? }\end{array}$ & $\begin{array}{l}\text { 3. Juadah berbuka } \\
\text { puasa dan sahur } \\
\text { sepanjang Ramadan? }\end{array}$ & $\begin{array}{l}\text { 3. Spa dan kolam } \\
\text { renang terpisah } \\
\text { antara jantina? }\end{array}$ \\
\hline $\begin{array}{l}\text { 4. Dapur mendapat } \\
\text { sijil halal? }\end{array}$ & $\begin{array}{l}\text { 4. Tanda arah kiblat di } \\
\text { dalam bilik? }\end{array}$ & $\begin{array}{l}\text { 4. Perkhidmatan } \\
\text { makanan halal di } \\
\text { bilik? Restoran halal } \\
\text { di sekitar hotel? }\end{array}$ & $\begin{array}{l}\text { 4. Spa, kolam renang } \\
\text { dan gimnasium } \\
\text { khusus untuk wanita? }\end{array}$ \\
\hline $\begin{array}{l}\text { 5. Semua restoran } \\
\text { yang mendapat sijil } \\
\text { halal }\end{array}$ & $\begin{array}{l}\text { 5. Segala prasarana } \\
\text { untuk setiap penghuni } \\
\text { Muslim bersolat. }\end{array}$ & $\begin{array}{l}\text { 5. Juadah berbuka } \\
\text { puasa dan sahur } \\
\text { sepanjang Ramadan } \\
\text { serta pengangkutan } \\
\text { ke masjid? }\end{array}$ & \\
\hline $\begin{array}{l}\text { 6. Hanya makanan } \\
\text { halal yang dibenarkan } \\
\text { di hotel. }\end{array}$ & & & \\
\hline
\end{tabular}

Dalam program penafaran, Crescentrating menjadikan keperluan perkhidmatan berasaskan kepercayaan (faith-based service needs) dalam penentuan kriteria penarafan. Berdasarkan kajian yang dilakukan, pada tahun 2009 didapati terdapat enam kunci asas kepercayaan yang mempengaruhi kepenggunaan pelancong Muslim iaitu: makanan halal, prasarana solat, perkhidmatan sepanjang Ramadan, tandas mesra air, tiada aktiviti tidak halal serta prasarana dan perkhidmatan rekreasi dengan privasi. Pada tahun 2019, berdasarkan kajian semula terhadap keperluan perkhidmatan berasaskan kepercayaan dalam (faith-based service needs), Crescentrating menambah tiga lagi kunci asas kepercayaan iaitu: bebas Islamophobia, faktor penyebab sosial (social causes) dan pengalaman Muslim tempatan (MastercardCrescentRating 2019). 
Tambahan tiga elemen ini penting dalam penilaian terhadap keperluan pelancong Muslim. Islamophobia menjadi satu isu bagi sebahagian negara. Ia boleh menimbulkan kebimbangan kepada pelancong Muslim terhadap keselamatan diri dan keluarga. Justeru ia dianggap sebagai keperluan paling asas (need to have) bagi pelancong Muslim. Faktor penyebab sosial juga menjadi daya tarikan bagi pelancong Muslim. Keprihatinan kepada masalah sosial sesuatu tempat mengundang empati dalam kalangan pelancong Muslim yang sukakan aktiviti sosial. Selain itu, kesedaran ekopelancongan dalam kalangan Muslim turut menjadi daya tarikan sebagai destinasi pelancongan Muslim. Elemen terakhir yang ditambah ialah pengalaman Muslim setempat. Elemen ini juga tidak kurang penting kerana sebahagian pelancong Muslim berminat untuk berinteraksi dengan masyarakat Muslim setempat serta mengalami budaya serta tradisi setempat. Kedua-dua elemen terakhir ini iaitu faktor penyebab sosial dan pengalaman Muslim setempat dianggap sebagai keperluan penting (good to have) bagi pelancong Muslim (Nabilah Ayuni 2019). Walaubagaimanapun, ketiga-tiga elemen tambahan ini masih lagi belum dimasukkan ke dalam Crescenrating Standard yang digunapakai sehingga hari ini.

\section{Kriteria Salam Standard}

Berbeza dengan Crescentrating Standard, Salam Standard membahagikan kategori hotel mesra Muslim kepada empat kategori sebagaimana jadual berikut (Salam Standard 2020):

Jadual 4: Kriteria Salam Standard

\begin{tabular}{|c|l|}
\hline Kategori & \multicolumn{1}{c|}{ Kriteria } \\
\hline \multirow{3}{*}{ Bronze } & $\begin{array}{c}\text { - } 100 \% \text { bilik mengandungi bilik mandi atau tandas } \\
\text { - Menyediakan sejadah atau berdasarkan permintaan } \\
\text { - Tanda arah qiblat tersedia di dalam bilik atau bersedia menunjukkan arah qiblat } \\
\text { berdasarkan permintaan }\end{array}$ \\
\hline \multirow{3}{*}{ Silver } & $\begin{array}{l}\text { Semua kriteria dalam kategori Bronze dipenuhi dan ditambah: } \\
\text { - Senarai restoran halal sekitar hotel tersedia di dalam bilik (atau boleh diminta } \\
\text { untuk disediakan) }\end{array}$ \\
& $\begin{array}{l}\text { - Tiada minuman beralkohol di mini-bar bilik (atau boleh diminta untuk } \\
\text { dikeluarkan sebelum pelanggan sampai) }\end{array}$ \\
\hline \multirow{3}{*}{ Gold } & $\begin{array}{l}\text { Semua kriteria dalam kategori Bronze dan Silver dipenuhi dan ditambah: } \\
- \text { Menawarkan makanan yang memperoleh sijil halal (sarapan pagi dan/atau } \\
\text { perkhidmatan ke bilik) pensijilan oleh badan pensijilan tempatan yang } \\
\text { bertauliah (contohnya di Malaysia pensijilan oleh JAKIM) }\end{array}$ \\
\hline Platinum & $\begin{array}{l}\text { Semua kriteria dalam kategori Bronze, Silver dan Gold dipenuhi dan ditambah: } \\
- \text { Seluruh premis hotel bebas minuman beralkohol. }\end{array}$ \\
\hline
\end{tabular}

\section{Standard Hotel Mesra Muslim di Malaysia Menurut Perspektif Maqasid Syariah}

al-Raysuni (1993) mendefinisikan Maqasid Syariah sebagai objektif yang menjadi sasaran pembinaan Syariat demi kepentingan manusia. Berdasarkan definisi ini, difahami bahawa yang menentukan objektif tersebut ialah Allah SWT sebagai Pemilik Syariat Matlamat daripada objektif tersebut untuk memberi kebaikan kepada manusia. Para sarjana Muslim telah membuat penyelidikan terperinci terhadap al-Quran dan al-Sunnah untuk mengenalpasti objek-objektif Syariat dan mereka mendapati objektif tersebut terangkum dalam lima sasaran iaitu agama, nyawa, akal, maruah dan harta. al-Ghazali (1993) menegaskan: "Maqasid Syariah daripada penciptaan makhluk terdapat lima iaitu menjaga mereka dari sudut agama, nyawa, akal, keturunan dan harta mereka".

Kelima-lima perkara ini merupakan sasaran yang menyeluruh, asasi dan luhur bagi keperluan manusia. Penjagaan lima perkara tersebut akan memberikan maslahah (kebaikan) kepada manusia, sebaliknya pengabaiannya akan mendatangkan mafsadah (keburukan) kepada 
manusia (al-Qahtani 2015). Justeru, pemeliharaan lima perkara ini sangat penting bagi mencapai sasaran Syariat yang diistilahkan sebagai Maqasid Syariah. al-Shatibi (2004) menyatakan penjagaan (hifz) kelima-lima maqasid tersebut berlaku dalam dua aspek. Pertama: penjagaannya dari aspek positif (janib al-wujud) yang bermaksud apa sahaja perkara yang dapat membangunkan dan meneguhkannya. Kedua: penjagaannya dari aspek negatif (janib al-'adam) yang bermaksud menghalangnya daripada sebarang perkara yang boleh mencacatkannya.

Penjagaan agama (hifz al-din) merupakan maqasid paling utama. Antara elemen penjagaan agama dari sudut positif ialah melaksanakan ibadat. Pelaksanaan ibadat wajib atau fardu ain merupakan perkara paling minimum bagi individu dari aspek penjagaan agama (alQadiri 2001; Hamdan 2012). Justeru itu, sesebuah hotel hendaklah menyediakan prasarana yang bersesuaian bagi penghuni Muslim melaksanakan ibadat. Perkara wajib yang berkaitan penghuni hotel ialah solat dan puasa. Untuk melaksanakan solat, paling asas penghuni memerlukan air untuk mengangkat hadas, menyuci najis dan melaksanakan solat di dalam bilik yang dihuni dengan menghadap ke arah qiblat. Namun, jika pihak hotel menyediakan ruang khusus untuk solat seperti musolla yang lengkap ia akan memberi keselesaan bagi penghuni untuk melaksanakan solat secara berjamaah dalam keadaan lebih sempurna. Pada hari Jumaat pula penghuni hendaklah mendapat informasi berkenaan masjid berdekatan. Jika pihak hotel menyediakan pengangkutan kepada yang memerlukan itu merupakan nilai tambah bagi sesebuh hotel mesra Muslim. Bagi pelaksanaan puasa pula, sewajarnya pihak hotel menstruktur jadual makan supaya penghuni dapat bersahur dan berbuka puasa sepanjang Ramadan dengan sempurna. Jadual makan bagi yang tidak berpuasa diteruskan sebagaimana biasa sebagai kemudahan bagi yang uzur syar'i. Penjagaan agama dari sudut negatif pula ialah tindakan menghalang anasir-anasir yang boleh menggugah pegangan agama seseorang. Pengusaha hotel hendaklah memastikan bilik yang dihuni oleh orang Muslim tidak disediakan Bible dan tidak dihias dengan patung, gambar atau simbol yang bercanggah dengan akidah Islam. Dekorasi hotel secara keseluruhan juga perlu diperhalusi supaya tidak memberi kesan negatif terhadap kepercayaan penghuni Muslim.

Penjagaan nyawa (hifz al-nafs) pula ialah segala tindakan yang memelihara manusia daripada sebarang kecacatan sama ada dari sudut positif (wujud) atau negatif ('adam). Penjagaan nyawa dari sudut positif antaranya ialah pensyariatan perkahwinan, larangan aktiviti pemandulan dan pengguguran bayi. Makan minum, ubatan-ubatan dan riadah juga termasuk dalam objektif penjagaan nyawa. Penjagaan nyawa dari sudut negatif pula ialah seperti pensyariatan hukuman qisas, larangan mencederakan orang lain, hukum mempertahan diri dan tindakan di bawah paksaan (al-Mabid 2005). Dalam konteks hotel, perkara yang paling berkaitan dengan penjagaan nyawa dari sudut positif ialah makanan dan minuman. Pihak hotel hendaklah menyediakan makanan dan minuman yang halal kepada penghuni atau sekurang-kurangnya memberikan informasi berkenaan restoran yang halal di kawasan sekitar. Namun, kewujudan restoran yang mempunyai sijil halal di dalam premis hotel akan memberi keselesaan yang lebih kepada penghuni. Selain makan minum, jika pihak hotel menyediakan ruangan dan kelengkapan riadah seperti gimnasium, kolam renang dan kawasan rekreasi ia juga menepati kehendak penjagaan nyawa asalkan tidak membawa kepada pergaulan bebas dan pendedahan aurat. Untuk mengekal tubuh badan sihat, bilik dan kawasan hotel hendaklah dipastikan berada dalam keadaan yang sentiasa bersih dan bebas daripada kotoran dan agen pembawa penyakit. Di samping itu, pihak hotel boleh menawarkan khidmat laundry bagi yang memerlukan.

Penjagaan nyawa dari sudut negatif bagi sesebuah hotel pula ialah pemeliharaan dan kawalan keselamatan yang melibatkan pengawal keselamatan yang terlatih, kamera litar tertutup (cctv), alat pengesan asap, pemadam api, sistem semburan air, hos bomba, lif bomba, pintu kecemasan dan rintangan api, panduan kecemasan, peti pertolongan cemas, larangan merokok di kawasan awam, pencahayaan yang cukup, kawasan yang bersih dan lain-lain aspek keselamatan sama ada di bilik, kolam renang, gymnasium dan kawasan parkir. Pihak hotel juga mestilah mempunyai garis panduan dan prosedur operasi standard (standard operating procedure) serta 
memberi latihan secukupnya kepada kakitangan untuk menghadapi situasi kecemasan. Hotel mesra Muslim tidak wajar kompromi berkaitan isu keselamatan. Malah keselamatan merupakan aspek yang paling penting bagi sesebuah hotel di samping keselesaan. Ia merupakan antara matlamat utama seseorang memilih hotel sebagai tempat penginapan. Atas kepentingan ini, Safehotels Alliance sebuah syarikat di Sweden mengambil inisiatif menawarkan khidmat akreditasi hotel dari sudut keselamatan sejak tahun 2015 (Safetyhotels.com 2018). Selain daripada penjagaan nyawa, aspek keselamatan juga berkaitan rapat dengan penjagaan harta (hifz al-mal) kerana penjenayah seringkali mengancam keselamatan diri mangsa untuk melakukan rompakan.

Penjagaan akal (hifz al-'aql) secara positif ialah mendorong dan mengembangkan penggunaan akal seperti berfikir, mengkaji dan mempelajari pelbagai ilmu. Penjagaan akal secara negatif pula ialah menghalang penggunaan apa sahaja yang boleh menghilangkan akal manusia seperti arak dan dadah serta perkara-perkara yang menghalang fungsi penciptaan akal (Reena \& Huda 2019). Walaupun memupuk manusia supaya berfikir tidak kelihatan jelas dalam peranan sesebuah hotel, namun secara tidak langsung elemen ini boleh diterapkan dalam beberapa prasarana yang ditawarkan. Antaranya ialah rancangan televisyen yang berbentuk informasi hendaklah diperbanyakkan berbanding rancangan berbentuk hiburan semata-mata. Ruangan bacaan serta poster-poster yang dipaparkan perlu mengandungi maklumat yang berguna. Ia sedikit sebanyak dapat memberi kesan positif kepada penghuni. Dari aspek negatif penjagaan akal, peranan hotel amat jelas dalam memastikan tiada minuman beralkohol disediakan kepada penghuni sama ada di restoran, kafe dan mini-bar di dalam bilik hotel serta tiada perkhidmatan penghantaran minuman tersebut ke bilik. Bagi Muslim, meminum arak atau apa-apa minuman beralkohol sememangnya ditegah, malah sebagai tindakan pencegahan ia tidak wajar berada di dalam bilik hotel yang didiami penghuni Muslim. Oleh itu, sekurang-kurangnya pihak hotel hendaklah bersedia untuk mengeluarkan minuman beralkohol daripada bilik hotel sebelum ketibaan penghuni Muslim. Syarat seumpama ini dipraktik oleh sebahagian agensi akreditasi hotel halal sebagaimana yang dilakukan oleh Halalinn.com (COMCEC 2016). Sebaiknya, minuman beralkohol tidak dibenarkan sama sekali dibawa masuk ke premis hotel kerana ia boleh menimbulkan rasa kurang selesa dalam kalangan penghuni Muslim.

Penjagaan keturunan (hifz al-nasl) dari sudut positif ialah tindakan yang dapat mengekal dan melestarikan umat menerusi perkahwinan. Penjagaan keturunan dari sudut negatif pula ialah menghalang sebarang tindakan yang menghalang atau mencacatkan kelestarian umat menurut kehendak syarak seperti berzina (al-Rays 2012). Penjagaan maruah (hifz al-iird) pula bermaksud segala tindakan yang bertujuan menjaga kesucian manusia. Ia merupakan tonggak kekhalifahan manusia sebagai insan mulia. Oleh itu, sebahagian ulama seperti al-Ghazali dalam kitab Ihya' 'Ulum al-Din, 'Izz al-Din Ibn 'Abd al-Salam, al-Tufi, Ibn al-Subki, Ibn al-Najjar dan alShawkani menambah penjagaan maruah sebagai kulliyyat keenam dalam Maqasid Syariah (alDuwayhi 2005). Al-Zarkashi (1992) pernah berhujah dalam hal ini dengan katanya: "Kebiasaan bagi orang yang berakal sanggup mengorbankan nyawa dan hartanya tetapi tidak sekali-kali mengorbankan maruahnya. Sesuatu yang dipertahankan dalam keadaan darurat seumpama ini lebih utama dikira sebagai perkara daruriyyat".

Oleh itu, perbincangan berkenaan penjagaan keturunan perlu dirangkum sekali dengan penjagaan maruah kerana kepentingannya yang tidak dapat disangkal lagi. Jika dilihat kepada penjagaan dari sudut positif iaitu perkahwinan, ia bukanlah sesuatu perkara daruriyyat (keperluan utama) bagi sesebuah hotel kerana fungsi hotel hanyalah sebagai tempat perlindungan. Jika hotel menyediakan ruang untuk melaksanakan akad dan jamuan perkahwinan, ia hanya sebagai perkara tambahan (tahsiniyyat) kepada fungsi utama hotel. Namun jika ia dilakukan, ia hendaklah memelihara semua kulliyyat yang lain dalam Maqasid Syariah. Penjagaan keturunan dan juga maruah dari sudut positif pula ialah pencegahan zina dan penjagaan aurat. Untuk mencapai objektif ini, pihak hotel hendaklah memastikan penghuni hotel terutama dalam kalangan Muslim ialah pasangan yang sah. Pihak hotel juga hendaklah berusaha 
supaya tidak berlaku percampuran jantina di kawasan-kawasan tertentu seperti di kolam renang, gimnasium dan spa. Perkara ini boleh diatasi dengan menyediakan tempat berasingan atau sekurang-kurang menyediakan jadual yang memisahkan antara jantina. Pihak hotel juga tidak boleh menawarkan hiburan atau pakej rekreasi serta permainan yang menggalakkan pergaulan bebas antara lelaki dan wanita. Hiburan yang ditawarkan mestilah tidak mengandungi elemenelemen yang bertentangan dengan syariat seperti muzik liar, lagu-lagu yang yang mengkhayalkan dan pakaian yang mendedahkan aurat. Capaian internet menerusi wifi yang disediakan perlu mempunyai keupayaan untuk menapis unsur-unsur kelucahan dan pronografi.

Penjagaan harta (hifz al-mal) dari sudut positif ialah usaha untuk mendapatkan dan memiliki harta. Penjagaan harta dari sudut negatif pula ialah memelihara harta daripada musnah atau berkurangan seperti pengawasan harta daripada dicuri, pengharaman pembaziran, bayaran ganti rugi atas kemusnahan atau kerosakan, sistem muamalat, zakat dan wakaf serta pengharaman riba (Mulawi \& al-Mesawi 2016). Penjagaan harta dari sudut positif bukan perkara daruriyyat (keperluan utama) bagi hotel kerana fungsi utama hotel ialah sebagai tempat penginapan. Namun ia boleh dianggap sebagai perkara tahsiniyyat (pelengkap keperluan), lebihlebih lagi hotel dalam sejarah Islam pada zaman dahulu kebiasaannya berfungsi sebagai tempat persinggahan para peniaga dan penuntut ilmu (al-Sirjani 2009). Antara keperluan ahli perniagaan yang perlu diberi keutamaan oleh hotel ialah perkhidmatan wifi berkelajuan tinggi, bilik mesyuarat dengan prasarana yang lengkap, penghantaran makanan ke bilik, kafe dan lainlain. Penjagaan harta dari sudut negatif berkait rapat dengan penjagaan nyawa dari sudut negatif yang lalu. Segala pencerobohan yang sering berlaku terhadap diri dan nyawa seseorang boleh berlaku terhadap harta. Selain daripada prasarana berkaitan penjagaan nyawa yang telah disenaraikan sebelum ini, pihak hotel hendaklah menyediakan kotak keselamatan (safety deposit box) di dalam setiap bilik untuk kegunaan pengguna, khidmat bilik kebal (safe deposit vault), rondaan pengawal keselamatan secara berkala, kawalan pintu keluar masuk yang ketat, lif beroperasi berdasarkan kad penghuni dan staf yang terlatih dengan nilai integriti. Walaupun menjaga harta adalah tanggungjawab individu, namun pihak hotel hendaklah memastikan keselamatan hotel berada tahap yang maksimum. Jaminan keselamatan merupakan pakej lengkap yang diharapkan oleh penghuni daripada hotel. Oleh itu, dalam menentukan standard hotel mesra Muslim, elemen keselamatan hendaklah dijadikan sebagai salah satu kriteria utama yang tidak boleh ditolak ansur.

Jika dilihat standard hotel mesra Muslim MS2610: 2015, Crescentrating Standard dan Salam Standard berdasarkan perspektif Syariah yang telah dibincangkan, masih kelihatan beberapa kekurangan yang ketara sebagaimana jadual berikut:

\section{Jadual 5: Standard MS2610: 2015, Crescentrating Standard dan Salam Standard Berdasarkan Kulliyyat Maqasid Syariah}

\begin{tabular}{|c|l|c|c|c|}
\hline $\begin{array}{c}\text { Kulliyyat } \\
\text { Maqaasid } \\
\text { Syariah }\end{array}$ & \multicolumn{1}{|c|}{ Prasarana Berkaitan } & MS2610:2015 & $\begin{array}{c}\text { Crescentrating } \\
\text { Standard }\end{array}$ & $\begin{array}{c}\text { Salam } \\
\text { Standard }\end{array}$ \\
\hline \multirow{5}{*}{$\begin{array}{l}\text { Penjagaan } \\
\text { Agama }\end{array}$} & $\begin{array}{l}\text { Solat: sejadah, telekung, arah } \\
\text { qiblat, jadual solat, musolla }\end{array}$ & $/$ & $/$ & $/$ \\
\cline { 2 - 5 } & Puasa: iftar dan sahur & $/$ & $/$ & $\mathrm{X}$ \\
\cline { 2 - 5 } & $\begin{array}{l}\text { Prasarana wuduk dan mandi } \\
\text { wajib }\end{array}$ & $/$ & $/$ & $/$ \\
\cline { 2 - 5 } & $\begin{array}{l}\text { Prasarana menyuci najis } \\
\text { Solat Jumaat: informasi } \\
\text { berkenaan masjid } \\
\text { berhampiran }\end{array}$ & $\mathrm{X}$ & $/$ & $\mathrm{X}$ \\
\cline { 2 - 5 } & $\begin{array}{l}\text { Tiada kitab suci selain al- } \\
\text { Quran di dalam bilik }\end{array}$ & $\mathrm{X}$ & $\mathrm{X}$ & $\mathrm{X}$ \\
\hline
\end{tabular}




\begin{tabular}{|c|c|c|c|c|}
\hline & $\begin{array}{|lr|}\begin{array}{l}\text { Dekorasi bilik } \\
\text { bercanggah } \\
\text { kepercayaan Islam }\end{array} & \text { tengan } \\
\end{array}$ & $\mathrm{X}$ & $\mathrm{X}$ & $\mathrm{X}$ \\
\hline & 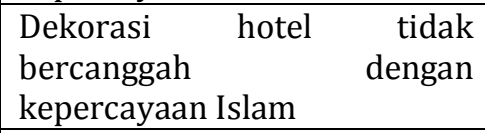 & $X$ & $\mathrm{X}$ & $\mathrm{X}$ \\
\hline \multirow{8}{*}{$\begin{array}{l}\text { Penjagaan } \\
\text { Nyawa }\end{array}$} & Makanan dan minuman halal & I & I & I \\
\hline & Restoran diiktiraf halal & I & 1 & 1 \\
\hline & $\begin{array}{l}\text { Ruangan riadah: seperti } \\
\text { gimnasium, kolam renang }\end{array}$ & / & / & $\mathrm{X}$ \\
\hline & $\begin{array}{l}\text { Bersih: bilik dan kawasan } \\
\text { hotel }\end{array}$ & / & / & / \\
\hline & $\begin{array}{l}\text { Kawalan keselamatan: seperti } \\
\text { pengawal, cctv }\end{array}$ & $\mathrm{X}$ & $\mathrm{X}$ & $\mathrm{X}$ \\
\hline & $\begin{array}{l}\text { Kawalan kebakaran: seperti } \\
\text { alat pengesan dan pemadam } \\
\text { api }\end{array}$ & $X$ & $\mathrm{X}$ & $\mathrm{X}$ \\
\hline & $\begin{array}{l}\text { Kawalan situasi kecemasan: } \\
\text { seperti sop dan staf terlatih }\end{array}$ & $\mathrm{X}$ & $\mathrm{X}$ & $\mathrm{X}$ \\
\hline & Larangan merokok & $\mathrm{X}$ & $\mathrm{X}$ & $\mathrm{X}$ \\
\hline \multirow{4}{*}{ Penjagaan Akal } & $\begin{array}{l}\text { Memperbanyakkan rancangan } \\
\text { tv berinformatif }\end{array}$ & $\mathrm{X}$ & $\mathrm{X}$ & $\mathrm{X}$ \\
\hline & Menyediakan ruangan bacaan & $\mathrm{X}$ & $\mathrm{X}$ & $\mathrm{X}$ \\
\hline & $\begin{array}{l}\text { Tidak menyediakan minuman } \\
\text { beralkohol: restoran, kafe dan } \\
\text { mini-bar }\end{array}$ & / & $\begin{array}{l}\text { Pentafsiran } \\
\text { berdasarkan } \\
\text { terma } \\
\text { "makanan dan } \\
\text { minuman halal" }\end{array}$ & / \\
\hline & $\begin{array}{l}\text { Larangan memasukkan } \\
\text { minuman beralkohol }\end{array}$ & / & $\begin{array}{l}\text { Pentafsiran } \\
\text { berdasarkan } \\
\text { terma } \\
\text { "makanan dan } \\
\text { minuman halal" }\end{array}$ & / \\
\hline \multirow{4}{*}{$\begin{array}{l}\text { Penjagaan } \\
\text { Keturunan }\end{array}$} & $\begin{array}{l}\text { Melarang pasangan tidak } \\
\text { berkahwin berkongsi bilik }\end{array}$ & $\mathrm{X}$ & $\mathrm{X}$ & $\mathrm{X}$ \\
\hline & \begin{tabular}{|lrr}
\multicolumn{3}{|l|}{ Memisahkan ruang atau jadual } \\
penggunaan kolam renang, \\
gimnasium dan \\
berdasarkan jantina
\end{tabular} & / & / & / \\
\hline & $\begin{array}{l}\text { Bebas daripada pakej rekreasi } \\
\text { dan permainan yang } \\
\text { menggalakkan pergaulan } \\
\text { bebas }\end{array}$ & $\mathrm{X}$ & $\mathrm{X}$ & $\mathrm{X}$ \\
\hline & \begin{tabular}{|ll} 
Bebas daripada hiburan \\
melalaikan
\end{tabular} & $\mathrm{X}$ & / & $\mathrm{X}$ \\
\hline \multirow{5}{*}{$\begin{array}{l}\text { Penjagaan } \\
\text { Harta }\end{array}$} & $\begin{array}{l}\text { Kotak keselamatan di dalam } \\
\text { bilik }\end{array}$ & $\mathrm{X}$ & $\mathrm{X}$ & $\mathrm{X}$ \\
\hline & Bilik kebal & $\mathrm{X}$ & $\mathrm{X}$ & $\mathrm{X}$ \\
\hline & Rondaan berkala & $\mathrm{X}$ & $\mathrm{X}$ & $\mathrm{X}$ \\
\hline & Kawalan pintu masuk & $\mathrm{X}$ & $\mathrm{X}$ & $\mathrm{X}$ \\
\hline & $\begin{array}{l}\text { Lif beroperasi menggunakan } \\
\text { kad }\end{array}$ & $\mathrm{X}$ & $\mathrm{X}$ & $\mathrm{X}$ \\
\hline
\end{tabular}

Berdasarkan jadual di atas, standard hotel mesra Muslim yang diperkenalkan kelihatan masih banyak kekurangan menurut perspektif Maqasid Syariah. Dalam bahagian penjagaan 
agama, hanya aspek penjagaan agama dari sudut positif yang ditekankan. Hampir semua standard menjadikan ibadat iaitu solat dan puasa serta perkara yang berkaitan dengan bersuci sebagai perkara yang dinilai. Namun elemen penjagaan agama dari aspek negatif seperti tiada dekorasi yang berlawanan dengan Islam tidak terdapat dalam ketiga-tiga standard tersebut. Hal yang sama dapat dilihat dalam bahagian penjagaan nyawa. Langkah-langkah untuk mengawal perlakuan jenayah, keadaan kebakaran dan kecemasan tidak dinyatakan dalam standard-standard tersebut. Dalam bahagian penjagaan keturunan, standard-standard tersebut tidak memestikan pihak hotel melakukan saringan terhadap pasangan penghuni dan pakej-pakej sampingan yang ditawarkan. Oleh itu, ruang untuk melakukan aktiviti tidak sihat seperti bersedudukan tanpa ikatan perkahwinan dan pergaulan bebas antara lelaki dan perempuan dalam acara-acara tertentu masih wujud. Malah dalam bahagian penjagaan harta, kelihatan standard-standard tersebut sama sekali tidak menjadikannya sebagai elemen yang dinilai.

Kesimpulannya, standard-standard yang dirujuk dalam penawaran hotel mesra Muslim di Malaysia iaitu MS2610: 2015 Muslim Friendly Hospitality Services - Requirements, Crescentrating Standard dan Salam Standard tidak bersifat holistik pada perspektif Maqasid Syariah. Keselamatan nyawa dan harta tidak dijadikan sebagai elemen penting dalam penilaian yang ditawarkan. Keadaan ini tidak selari dengan fungsi hotel sebagai tempat perlindungan dan sama sekali bercanggah dengan kulliyyat utama Maqasid Syariah.

\section{Acknowledgement}

This publication is part of findings of research funded by Fundamental Research Grant Scheme (FRGS) FRGS/1/2019/SSI03/UKM/02/6.

\section{References}

Che Musa Che Omar, Noormuthaah Mohamad Ali Adaha, Hilyati Abdul Ghaffar \& Amirul Imran Mohd Ali. 2014. Shariah Compliance in Hotel Operations Using Islamic Tourism Product Index. Proceedings of International Conference on Tourism and Development: Growth and Diversity at Chiang Mai, Thailand. pp. 144-151.

Crescentrating. 2018. Get Your Hotel's Muslim Friendly services Audited and Rated. https://www.crescentrating.com/rating-accreditations/hotels.html. Retrieved: 15 Jan. 2020.

Cuesta-Valiño P, Bolifa F \& Núñez-Barriopedro E. 2020. Sustainable, smart and Muslim-friendly tourist destinations. Sustainability 12(5):1778-1791.

Department Standard of Malaysia. 2015. MS 2610: 2015 Muslim Friendly Hospitality Services Requirements. Cyberjaya: Ministry of Science, Technology and Innovation.

Dinar Standard. 2019. State of The Global Islamic Economy Report (SGIE) 2019/20. https://ceif.iba.edu.pk/pdf/state-of-global-islamic-economy-report-2019-20.pdf.

Retrieved: 16 January 2020.

al-Duwayhi, Ahmad ibn 'Abd Allah. 2005. Kulliyyat al-Shar': haqiqatuha, ahammiyyatuha li almujtahid, wa 'alaqatuha bi al-adillah al-juz'iyyah. Majallat Kulliyyat al-Shari'ah wa alQanun bi Asyut 17(2): 425-530.

Fisol, W. N. M., Suid, I. S., Saufi, M. S. A. M., \& Bahari, A. 2019. Islamic tourism development based on the scientific of the maqasid shari'ah framework. International Journal of Academic Research in Business \& Social Sciences 9(5): 784-795.

al-Ghazali, Abu Hamid Muhammad ibn Muhammad. 1993. al-Mustasfa min 'Ilm al-Usul. Beirut: Dar al-Kutub al-'Ilmiyyah.

Hamdan, Iyad Fawzi. 2012. Hifz al-din maqsad min maqasid al-shari'ah. Majallat Dirasat Da'awiyyah 23: 103-148. 
Hardius Usman, Nurdin Sobari \& Lia Estika Sari. 2020. Sharia motivation in Muslim tourism definition, is it matter?. Journal of Islamic Marketing 10(3): 709-723.

Islamic Toursim Centre. 2016. Muslim-Friendly Hospitality Services. https://itc.gov.my/industry/islamic-tourism-standards/Muslim-friendly-hospitalityservices. Retrieved: 9 Jan. 2020.

Junaidi Junaidi. 2020. Halal-friendly tourism and factors influencing halal tourism. Management Science Letters 10(8): 1755-1762.

al-Mabid, Muhammad Ahmad. 2005. Maslahat Hifz al-Nafs fi al-Shari'ah al-Islamiyyah. Kaherah: Mu'assasat al-Mukhtar.

Majdah Zawawi \& Noriah Ramli. 2017. "Shari'ah compliant hospitality services" or "Muslim friendly hospitality services": searching for a balance. Malaysian Journal of Consumer Family Economics 20(1): 28-37.

Mastercard-CrescentRating. 2019. Global Travel Index 2019 (GMTI 2019).

Mohd Hyrul Abu Karim, Rozila Ahmad \& Noor Azimin Zainol. 2017. Differences in hotel attributes: Islamic hotel and sharia compliant hotel in Malaysia. Journal of Global Business and Social Entrepreneurship (GBSE) 1(2): 157-169.

Mulawi, Shubayr Ahmad \& al-Mesawi, Muhammad al-Taher. 2016. Maqasid al-shari'ah fi alamwal wa wasa'iluha 'ind al-Imam Muhammad al-Tahir Ibn 'Ashur. al-Tajdid. 20 (39A): 235-265.

Nabilah Ayuni. 2019. Evolution of Muslim Traveler Faith-Based Service Needs. https://www.crescentrating.com/magazine/Muslim-travel/4000/evolution-of-Muslimtraveler-faith-based-service-needs.html. Retrieved: 15 January 2020.

Nor Azizah Tukirana \& Nor 'Azzah Kamri. 2018. Analisis pemakaian standard untuk pengurusan hotel patuh syariah di Malaysia. Online Journal of Research in Islamic Studies 5(2): 61-79.

Organisation of Islamic Cooperation. 2018. Strategic roadmap for development of Islamic tourism in OIC member countries. The Statistical, Economic and Social Research and Training Centre for Islamic Countries (SESRIC). Ankara: OIC.

Al-Qadiri, Abdullah Aham. 2001. Al-Islam wa Daruriyyat al-Hayah. Jedah: Dar al-Mujtama' li alNashr wa al-Tawzi'.

Al-Qahtani, Musfir ibn 'Ali. 2015. Understanding Maqasid al-Shari'ah: A Contemporary Perspective. Virginia: The International Institute of Islamic Thought.

Al-Rays, Sa'ad Jamil Salim. 2012. al-Nasl, Hifzuh wa Tanzimuh, Dirasah Fiqhiyyah. Tesis Sarjana. Kulliyyat al-Tarbiyyah. Universiti al-Azhar, Gaza.

Al-Raysuni, Ahmad. 1993. Nazariyyat al-Maqasid 'ind al-Imam al-Shatibi. Virginia: The International Institute of Islamic Thought.

Reena Samim Sadiq \& Huda 'Abd al-Khaliq 'Uthman. 2019. Hifz al-'aql wa dawruh fi islah almujtama' (al-idman 'ala al-al'ab al-iliktruniyyah). Majallat Midad al-Adab. Special Edition. 545-562.

Safetyhotels.com. 2018. https://safehotels.com/about. Retrieved: 19 January 2020.

Salam $\quad$ Standard. 2020. https://www.salamstandard.org/salam-standardcertification/certification-levels.html. Retrieved: 16 January 2020.

Al-Shatibi, Abu Ishaq Ibrahim ibn Musa. 2004. al-Muwafaqat fi Usul al-Shari'ah. Beirut: Dar alKutub al-'Ilmiyyah.

Al-Sirjani, Raghib. 2009. Ma dha Qaddam al-Muslimun li al-'Alam, Ishamat al-Muslimin fi alHadarah al-Insaniyyah. Kaherah: Mu'assasat Iqra'.

The Standing Committee for Economic and Commercial Cooperation of the Organization of the Islamic Cooperation (COMCEC). 2016. Muslim Friendly Tourism: Developing and Marketing MFT Products and Services in the OIC Member Countries. Ankara: COMCEC Coordination Office.

al-Zarkashi, Muhammad ibn Bahadur. 1992. al-Bahr al-Muhit fi Usul al-Fiqh. Edited by 'Abd alQadir 'Abd Allah al-'Ani. Ghardaqah: Dar al-Safwah. 